\title{
Hip microinstability: fact or fiction?
}

\author{
Pierre-Olivier Jean ${ }^{1} \cdot$ Marc R. Safran $^{2} \cdot$ Olufemi R. Ayeni $^{1}$ (])
}

Received: 8 October 2021 / Accepted: 2 December 2021 / Published online: 22 January 2022

(C) The Author(s) under exclusive licence to European Society of Sports Traumatology, Knee Surgery, Arthroscopy (ESSKA) 2021

Keywords Hip instability $\cdot$ Microinstability $\cdot$ Hip joint $\cdot$ Biomechanics $\cdot$ Capsular laxity $\cdot$ Labral tear $\cdot$ Femoral head

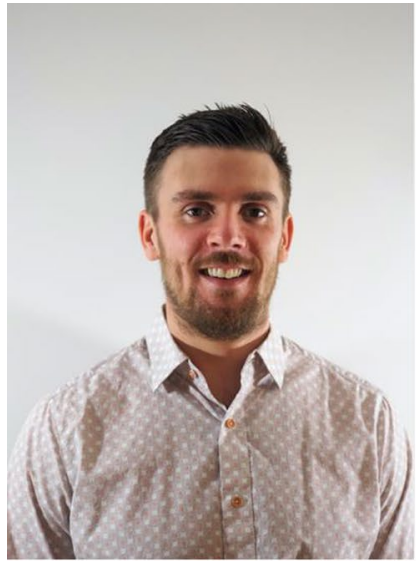

Dr. Pierre-Olivier Jean

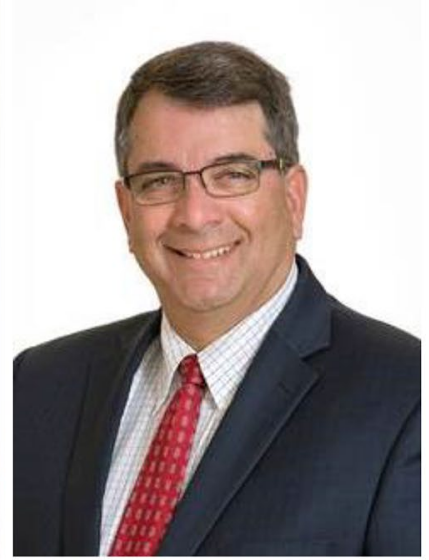

Dr. Marc R Safran

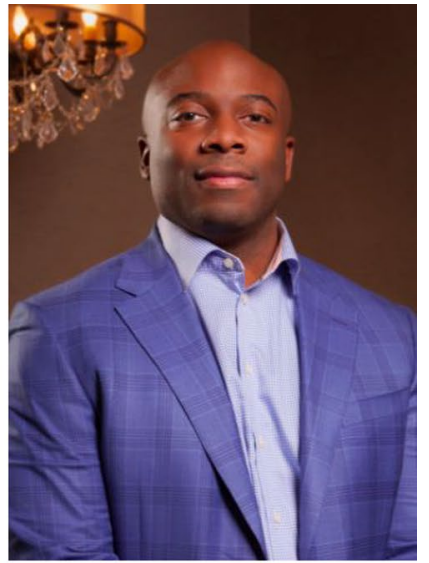

Dr. Olufemi R Ayeni
Hip instability, also termed "microinstability", awareness has increased recently, but it still remains a debated subject. The absence of general agreement comes partly from the fact that the hip is typically thought of as a very stable joint due to its high bony conformity and thick tissue envelope, the difficulty of examining the hip within its deep soft tissue envelop and the fact that patients infrequently complain of true instability [21]. Those who have pain related to hip instability generally complain of deep pain around the hip joint, groin, or inguinal crease [11,23]. Uncommonly some can complain of a sense of apprehension, or giving way with specific activities [21].

Olufemi R. Ayeni

ayenif@mcmaster.ca

1 Division of Orthopaedic Surgery, Department of Surgery, McMaster University, 1200 Main St West, 4E15, Hamilton, ON L8N 3Z5, Canada

2 Department of Orthopaedic Surgery, Stanford University Medical Center, 450 Broadway St, Pavillion A,

Redwood City, CA 94063, USA
It has been previously established that the hip does not simply rotate in its socket but also exhibits translational movements as well [1, 2, 6, 13, 16, 22]. Recently, biomechanical models have shown that capsular laxity increases femoral head rotation and translation [8-10]. Some light has also been shed on the capsule-labrum relationship; a recent biomechanical study has shown that a labral insufficiency will create more femoral head translation when the capsule is lax and its effect is less important when the capsule is intact [10]. The clinical implications of these newer findings remain to be elucidated but there is growing recognition that instability can lead to further degenerative changes of the hip joint $[1,14,16]$. One reason that could explain this phenomenon is that motion of the femoral head relative to the acetabulum puts stress on the capsule and labrum, injuring these structures. Those injuries would then increase translation of the femoral head in the acetabulum and an increasing amount of stress is placed on the labrum and capsule. This could perpetuate a spiral of instability and eventual degenerative changes within the hip joint. [21] 
The only available classification actually divides instability according to its etiology: bony abnormalities or hip dysplasia, connective tissues disorders, post-traumatic, microtraumatic, iatrogenic and idiopathic [4]. The multitude of different causes demonstrate its coexistence with other pathologies and can therefore confound the clinician. While there are some clinical or radiological signs that have been proposed [3, 7, 17, 18, 25], there are none that currently are pathognomonic or agreed upon, so the diagnosis depends on clinical experience and acumen. As such, the diagnosis can be relatively simple in patients with obvious bony anomalies or can also be very subtle in cases where no bony anomalies are found [11]. There is most likely a spectrum of instability, and it is critical to determine this in order to direct treatment, as many different techniques have been proposed $[4,5,12,15,19,20,24,26]$. Nonetheless, there is a lack of high-quality research that has evaluated the efficacy of the variety of existing management strategies. A good starting point should be a focus on developing consensus based criteria to standardize definitions, diagnostic criteria and treatments. Even though there is a growing body of evidence addressing hip instability, clinicians should be careful and proceed using evidence-based principles prior to proposing wide range of treatments in all forms (operative and non-operative). This will elevate the facts from fiction.

\section{References}

1. Charbonnier C, Kolo FC, Duthon VB, Magnenat-Thalmann N, Becker CD, Hoffmeyer P, Menetrey J (2011) Assessment of congruence and impingement of the hip joint in professional ballet dancers: a motion capture study. Am J Sports Med 39(3):557-566

2. Cvetanovich GL, Beck EC, Chalmers PN, Espinoza Orías AA, Stover MD, Inoue N, Nho SJ (2020) Assessment of hip translation in vivo in patients with femoracetabular impingement syndrome using 3-dimensional computed tomography. Arthrosc Sports Med Rehabil 2(2):e113-e120

3. d'Hemecourt PA, Sugimoto D, McKee-Proctor M, Zwicker RL, Jackson SS, Novais EN, Kim YJ, Millis MB, Stracciolini A (2019) Can dynamic ultrasonography of the hip reliably assess anterior femoral head translation? Clin Orthop Relat Res 477(5):1086-1098

4. De Giacomo AF, Lu Y, Suh DH, McGarry MH, Banffy M, Lee TQ (2021) Biomechanical comparison of capsular repair, capsular shift, and capsular plication for hip capsular closure: is a single repair technique best for all? Orthop J Sports Med 9(10):23259671211040096

5. Domb BG, Stake CE, Lindner D, El-Bitar Y, Jackson TJ (2013) Arthroscopic capsular plication and labral preservation in borderline hip dysplasia: two-year clinical outcomes of a surgical approach to a challenging problem. Am J Sports Med 41(11):2591-2598

6. Duthon VB, Charbonnier C, Kolo FC, Magnenat-Thalmann N, Becker CD, Bouvet C, Coppens E, Hoffmeyer P, Menetrey J (2013) Correlation of clinical and magnetic resonance imaging findings in hips of elite female ballet dancers. Arthroscopy 29(3):411-419

7. Economopoulos KJ, Kweon CY, Gee AO, Morris ST, Hassebrock JD, Chhabra A (2019) The pull test: a dynamic test to confirm hip microinstability. Arthrosc Sports Med Rehabil 1(1):e67-e74

8. Han S, Alexander JW, Thomas VS, Choi J, Harris JD, Doherty DB, Jeffers JRT, Noble PC (2018) Does capsular laxity lead to microinstability of the native hip? Am J Sports Med 46(6):1315-1323

9. Johannsen AM, Behn AW, Shibata K, Ejnisman L, Thio T, Safran MR (2019) The role of anterior capsular laxity in hip microinstability: a novel biomechanical model. Am J Sports Med 47(5):1151-1158

10. Johannsen AM, Ejnisman L, Behn AW, Shibata K, Thio T, Safran MR (2019) Contributions of the capsule and labrum to hip mechanics in the context of hip microinstability. Orthop J Sports Med 7(12):2325967119890846

11. Kalisvaart MM, Safran MR (2015) Microinstability of the hip-it does exist: etiology, diagnosis and treatment. J Hip Preserv Surg 2(2):123-135

12. Kalisvaart MM, Safran MR (2017) Hip instability treated with arthroscopic capsular plication. Knee Surg Sports Traumatol Arthrosc 25(1):24-30

13. Kapron AL, Aoki SK, Peters CL, Anderson AE (2015) In-vivo hip arthrokinematics during supine clinical exams: Application to the study of femoroacetabular impingement. J Biomech 48(11):2879-2886

14. Kolo FC, Charbonnier C, Pfirrmann CW, Duc SR, Lubbeke A, Duthon VB, Magnenat-Thalmann N, Hoffmeyer P, Menetrey J, Becker CD (2013) Extreme hip motion in professional ballet dancers: dynamic and morphological evaluation based on magnetic resonance imaging. Skelet Radiol 42(5):689-698

15. Larson CM, Stone RM, Grossi EF, Giveans MR, Cornelsen GD (2015) Ehlers-Danlos syndrome: arthroscopic management for extreme soft-tissue hip instability. Arthroscopy 31(12):2287-2294

16. Mitchell RJ, Gerrie BJ, McCulloch PC, Murphy AJ, Varner KE, Lintner DM, Harris JD (2016) Radiographic evidence of hip microinstability in Elite Ballet. Arthroscopy 32(6):1038-1044. e1031

17. Packer JD, Cowan JB, Rebolledo BJ, Shibata KR, Riley GM, Finlay AK, Safran MR (2018) The cliff sign: a new radiographic sign of hip instability. Orthop J Sports Med 6(11):2325967118807176

18. Packer JD, Foster MJ, Riley GM, Stewart R, Shibata KR, Richardson ML, Boutin RD, Safran MR (2020) Capsular thinning on magnetic resonance arthrography is associated with intra-operative hip joint laxity in women. J Hip Preserv Surg 7(2):298-304

19. Philippon MJ (2001) The role of arthroscopic thermal capsulorrhaphy in the hip. Clin Sports Med 20(4):817-829

20. Philippon MJ, Trindade CAC, Goldsmith MT, Rasmussen MT, Saroki AJ, Løken S, LaPrade RF (2017) Biomechanical assessment of hip capsular repair and reconstruction procedures using a 6 degrees of freedom robotic system. Am J Sports Med 45(8): $1745-1754$

21 Safran MR (2019) Microinstability of the hip-gaining acceptance. J Am Acad Orthop Surg 27(1):12-22

22. Safran MR, Lopomo N, Zaffagnini S, Signorelli C, Vaughn ZD, Lindsey DP, Gold G, Giordano G, Marcacci M (2013) In vitro analysis of peri-articular soft tissues passive constraining effect on hip kinematics and joint stability. Knee Surg Sports Traumatol Arthrosc 21(7):1655-1663

23. Shu B, Safran MR (2011) Hip instability: anatomic and clinical considerations of traumatic and atraumatic instability. Clin Sports Med 30(2):349-367

24. Torres SJ, Banffy MB (2020) Arthroscopic hip capsular plication with augmentation using a bioinductive collagen implant. Arthrosc Tech 9(7):e1011-e1015 
25. Truntzer JN, Hoppe DJ, Shapiro LM, Safran MR (2019) Can the FEAR index be used to predict microinstability in patients undergoing hip arthroscopic surgery? Am J Sports Med 47(13):3158-3165

26. Wylie JD, Beckmann JT, Maak TG, Aoki SK (2016) Arthroscopic capsular repair for symptomatic hip instability after previous hip arthroscopic surgery. Am J Sports Med 44(1):39-45
Publisher's Note Springer Nature remains neutral with regard to jurisdictional claims in published maps and institutional affiliations. 